\title{
Educational challenges in teaching nursing ethics: Perspectives of educators in Japan
}

\author{
Mari Tsuruwaka* \\ Ethics/Bioethics, Graduate School of Nursing Sciences, St. Luke's International University, Tokyo, Japan
}

Received: January 9, 2018

DOI: $10.5430 /$ jnep.v8n10p152
Accepted: May 23, 2018

Online Published: June 8, 2018

\begin{abstract}
Background: While nursing ethics is becoming accepted as an independent subject in Japanese universities, there are many issues concerning the education. The purpose of this study was to anew investigate nursing ethics programs in university, to reveal the difficulties that nursing ethics educators in Japanese nursing bachelor's degree programs faced and educational challenges, and to examine the best form of nursing ethics education.

Methods: A self-administered questionnaire survey to nursing ethics educators in 235 nursing bachelor's degree programs in Japan was conducted. The questionnaire mainly asked about an overview of nursing ethics programs, the difficulties educators experienced and educational challenges, and the association of ethics education with nursing practice.

Results: The return rate of the questionnaire was $29.7 \%$. Methods of group discussion based on case studies were common, and patients' rights and analytical approaches to ethical issues were common topics. Many of the subjects faced difficulties in nursing ethics education: curriculum, students' circumstances, students' readiness and abilities, the characteristics of ethical problems, and educators' abilities. The educators suggested that students should continue to learn nursing ethics over a few school years according to a curriculum built in a step-by-step, systematic manner.

Conclusions: This survey indicated that discussions regarding what educational goals in what school year should be offered to students were needed at each university. Cooperation between educators and practical training instructors on the contents of education, and a clear definition of expertise necessary for teaching nursing ethics were challenges to be accomplished as well.
\end{abstract}

Key Words: Nursing ethics education, Japan, Educational challenges in teaching nursing ethics, Nursing ethics educator

\section{BACKGROUND}

\subsection{Methodology and content of nursing ethics educa- tion}

Various studies on methodologies of ethics education to all students learning healthcare as well as medical doctors have been conducted due to its importance. ${ }^{[1-3]}$ Methodologies of ethics education, such as case studies, role-playing and simulations are similarly being sought for in some areas including engineering and business. ${ }^{[4,5]}$ It has been pointed out that nurses need to consider ethics all the time in their daily practices owing to their close relation with patients who need life support and care. ${ }^{[6,7]}$ Reed et al ${ }^{[8]}$ stated the necessity of ethics education by indicating the difference between dramatic ethics in clinical settings and continuing ethics. Nurses should be interested in what sort of character underlies individuals' dramatic ethics as well as in issues related to continuing ethics such as human rights, freedom, and independence. Since the work of nurses is characterized as continuous, holistic care of patients suffering various distress caused by illnesses, nurses need to think about ethics in

\footnotetext{
*Correspondence: Mari Tsuruwaka; Email: tsuruwaka@slcn.ac.jp; Address: Ethics/Bioethics, Graduate School of Nursing Sciences, St. Luke’s International University, 10-1 Akashi cho, Chuo ku, Tokyo, 104-0044, Japan.
} 
their daily practice, unlike people in other disciplines.

A variety of debates have already occurred regarding methodology and content of nursing ethics education. Both nursing students and educators were aware that ethical conflicts could be clarified using case studies and role-playing as an educational tool. ${ }^{[9-12]}$ Although case studies are helpful in considering ethical decision-making, ambiguity observed in the cases and time limit to discuss the cases appear to be disadvantageous. ${ }^{[13,14]}$ The importance of group discussions associated with case studies has also been acknowledged. ${ }^{[10,12,15]}$ Group discussions among students regarding ethical issues prompted them to listen to other students' ideas, positively accept them, and carefully express their own thoughts. ${ }^{[13,16-18]}$ A series of nursing ethics classes in Taiwan that involved both online learning based on 11 scenarios and face-to-face classroom lectures was found to increase students' level of satisfaction and improve their ability to analyze cases. ${ }^{[19]}$

Learning ethical theories as part of nursing education was considered effective. ${ }^{[14,20]}$ Despite a fact that approaches on a basis of ethical principles taught ethical frameworks, there were some cases in which these frameworks were employed by people to justify their actions rather than to deepen their ethical thoughts. ${ }^{[9,13]}$ Nursing students and educators believed that learning ethical codes was a foundation on which professionals rested. However, supplementary use of these codes was called for, since they provided only a general description. ${ }^{[10]}$ How professionals should learn ethics in a practical manner has been a matter to examine promptly. ${ }^{[21]}$ Learning ethical decision-making models was perceived as assistance in understanding ethical conflicts, cultivating more systematic thoughts, and developing problemsolving skills. ${ }^{[22,23]}$ It has been assumed to be important to link theories and practices in ethics education. ${ }^{[12,24]}$ Many thought that ethics education should be carried out, based on actual clinical practices. ${ }^{[25,26]}$ The need of opportunities for students to link nursing practices to theories through their reflective reports written in their practical training has been identified. ${ }^{[15]}$ Nursing students and educators perceived the need to devote a sufficient amount of time to ethics education. ${ }^{[9,10,14]}$ Students believed that it was best to take ethics classes at the first and last year during their four-year education. ${ }^{[27]}$ Some educators believed that ethics education was necessary before students learn in practical settings. ${ }^{[9,26]}$ While many nursing students and educators believed that ethics education and all nursing subjects should be integrated and provided during all four years of schooling, some thought that ethics education should be separate from other subjects to allow for a more systematic learning of the subject. ${ }^{[9,10]}$ The importance of the active contributions of nursing students and the use of ethical frameworks while discussing

Published by Sciedu Press case studies has been indicated. The necessity for an environment in which nursing students don't hesitate to reflect on ethical problems in such discussions, based on the values endorsed by the frameworks, has also been mentioned. ${ }^{[28,29]}$

\subsection{Current status and issues of nursing ethics educa- tion in Japan}

The "Report on the Improvement of Basic Nursing Education" released by the Ministry of Health, Labour and Welfare indicated that courses related to "the cultivation of basic skills that nurses can use to make ethical judgments" to be included in nursing programs would improve nursing ethics education. ${ }^{[30]}$ At the end of the 1990s, surveys of nursing ethics courses began. A survey of three-year nursing schools indicated that $16.3 \%$ offered nursing ethics as an independent course. ${ }^{[31]}$ Another survey resulted in $18.2 \% .^{[32]}$ Several researchers including the author surveyed syllabi in nursing bachelor's degree programs ${ }^{[33]}$ and obtained the figure of $42 \%$, which suggest that the number of independent courses was increasing year by year. Educators and nurses in charge of nursing ethics education in Japan were surveyed in terms of the content of the education by means of the Delphi method. 41 items were obtained: 20 of nursing ethics concepts such as patients' rights, 7 of codes of ethics, 13 of ethical problems and methodology, and one of the protection of rights in research. ${ }^{[34]}$

One of the issues of nursing ethics education in Japan was basic nursing education should be ready to prompt students to develop he ability to analyze ethical problems. ${ }^{[35]}$ Another issue was there were few educational opportunities in which clinical experience gained in practical training should be fully reviewed. ${ }^{[36]}$ I elucidated ethical problems that nursing students in Japan encountered during practical training and suggested that organic cooperation between nursing ethics courses and nursing practice should be built. ${ }^{[37]}$ A survey of nursing educators indicated that educators themselves had yet to acquire methods and materials of ethics education. ${ }^{[38]}$ In addition, there are few studies of educators who are involved in nursing ethics education. ${ }^{[39]}$ Studies of specific nursing ethics education in Japan began approximately 15 years ago, which suggests that it would be significant for nursing ethics educators to elucidate current problems in this area, including response to the problems that were discussed in initial studies.

The purpose of this study was to anew investigate nursing ethics programs in university, to reveal the difficulties and educational challenges that nursing ethics educators in Japanese nursing bachelor's programs faced, and to examine the best form of nursing ethics education. 


\section{MethodS}

\subsection{Study design}

This study was conducted using an anonymous selfadministered questionnaire. This was not a preexisting questionnaire and created by the researchers of this study.

In the questionnaire, there were questions asking the background of nursing ethics educators, and overall descriptions of an independent subject of nursing ethics education regarding its methodology and content. The questionnaire collected the following data related to its respondents in charge of nursing ethics education in Japanese nursing bachelor's degree programs: basic attributes such as sex, age, job position, nursing credentials, the years during which they received basic education, area of affiliation, type of university and its managing organization, reasons for being in charge of an ethics course, and nursing ethics education that the respondent had received; an overview of nursing ethics offered as an independent course such as required or elective course, assigned school year, type of class, whether a textbook is used, methods of evaluation, the number of educators in charge of the class, and educational goals.

The survey participants were asked about educational contents of nursing ethics as well in a multiple-response questionnaire. They responded to 13 major items and several minor items that were based on our previous study on syllabi of nursing ethics in Japanese nursing bachelor's degree programs. ${ }^{[25]}$ The major items included: ethical theories and ethical principles, definitions of nursing ethics, ethical codes and guidelines, history, basic concepts in nursing ethics, the dignity of life and the quality of life, issues related to patients' rights, confidentiality obligation and the protection of personal information, analytical approaches to ethical problems, safety and risk management, research ethics, ethics in each area of the nursing profession, ethical problems encountered by nursing students in the course of nursing practice.

In addition to these questionnaire items, a 4-point Likert scale was used to inquire about their perceptions regarding the association of ethics education with nursing practice and the degree of difficulty of nursing ethics education experienced by nursing educators of nursing ethics education. In addition, specific issues that they perceived to be related to nursing practice, reasons for difficulties in teaching the course, and issues to be discussed, were asked with a free description style.

The questionnaire was mailed to 235 nursing universities in Japan, and the supervisors of the programs were asked to distribute the forms. The survey was conducted in March 2015.

\subsection{Subjects}

The subjects were educators who taught independent nursing ethics courses in 235 Japanese nursing bachelor's degree programs or in a case where there were no independent courses, educators who taught nursing ethics classes that were part of basic nursing education.

\subsection{Ethical considerations}

Since all subjects received a written form of explanation of the purpose, methods, and ethical considerations of this study, the voluntariness of the study was ensured. We informed the subjects that the following steps would be taken: 1) the questionnaire would be anonymous and could not be used to identify any personal information, 2) returning the questionnaire by mail would be interpreted as consent to the survey, and no disadvantage would occur even if subjects wouldn't participate in the survey, 3) the questionnaire would be strictly kept in the locker of the researcher's office, which itself is always kept locked, 4) anonymized data would be stored for at least 5 years after it was publish in an academic journal and the data subsequently would be shredded and discarded, and 5) anonymity would be ensured when the data was published in an academic journal. This study was approved by the Institutional Review Board of St. Luke's International University (No. 14-071).

\subsection{Data analysis}

Each of the questionnaire items was analyzed with simple tabulation: the attributes of the nursing ethics educators in Japanese nursing bachelor's degree programs, educational content of an independent subject of nursing ethics, the degree of awareness of the association with nursing practice, and the degree of difficulty in teaching the course. The subjects answered four items by writing their ideas freely: what educators were aware of in terms of the association with nursing practice, why educators had difficulty in teaching nursing ethics, issues to be discussed about nursing ethics education, and on what respects in teaching educators placed importance. Each of these descriptions was summarized into one sentence without losing the meaning and decades of codes were created accordingly. These codes were classified by similarity and categories and sub-categories were defined. The words in double quotations described below are categories, and those in single quotations are sub categories.

\section{RESUlts}

\subsection{Basic attributes of the subjects}

The questionnaire return rate was $29.7 \%$ (70 responded). Table 1 provides the basic attributes of the respondents and their institutions of affiliation. Most of the respondents (90\%) were female, and more than $70 \%$ were in their 50s (43\%) and 
60s (30\%). Many of the respondents were professors (71\%). a high status like professors taught nursing ethics. They were Two respondents had no nursing credential and the rest had some types of nursing credentials. In the 1980s (45\%) and the 1970s (34\%), most of the educators received their basic nursing education. Their teaching career lasted for 20-29 years (35\%), 10-19 years (30\%), and 30 years or more $(23 \%)$. experienced in nursing education and belonged to the discipline of fundamental nursing. The types of universities that the educators were affiliated with were general universities $(64 \%)$ and colleges (26\%), and their managing organizations Many of the respondents belonged to the discipline of funda- ment (19\%), and local governments $(17 \%)$. mental nursing $(60 \%)$. In general, nursing professionals with

Table 1. Characteristics and background of respondents $(n=70)$

\begin{tabular}{|c|c|c|c|}
\hline Characteristics and background & & Number of respondents & Percentage (\%) \\
\hline \multirow{3}{*}{ Sex } & Female & 63 & 90 \\
\hline & Male & 4 & 6 \\
\hline & No response & 3 & 4 \\
\hline \multirow{5}{*}{ Age-group } & 30 ’s & 1 & 1 \\
\hline & 40 ’s & 17 & 24 \\
\hline & $50 ’ s$ & 30 & 43 \\
\hline & 60 ’s & 21 & 30 \\
\hline & No response & 1 & 1 \\
\hline \multirow{3}{*}{ Qualification } & $\mathrm{RN}$ & 49 & 70 \\
\hline & RN and PHN & 19 & 27 \\
\hline & No license & 2 & 3 \\
\hline \multirow{6}{*}{ Educators’ basic nursing education } & In 1969 or before & 9 & 13 \\
\hline & 1970s & 24 & 34 \\
\hline & 1980s & 31 & 45 \\
\hline & $1990 s$ & 3 & 4 \\
\hline & Elsewhere & 2 & 3 \\
\hline & No response & 1 & 1 \\
\hline \multirow{4}{*}{ Years of experience in teaching } & 1-9 years & 9 & 13 \\
\hline & 10-19 years & 21 & 30 \\
\hline & 20-29 years & 24 & 35 \\
\hline & Over 30 years & 16 & 23 \\
\hline \multirow{4}{*}{ Job title } & Professor & 49 & 71 \\
\hline & Associate professor & 16 & 23 \\
\hline & Lecturer & 3 & 4 \\
\hline & Assistant professor & 1 & 2 \\
\hline \multirow{9}{*}{ Fields of specialty } & Fundamental nursing & 42 & 60 \\
\hline & Adult nursing & 4 & 6 \\
\hline & Maternity nursing & 2 & 3 \\
\hline & Pediatric nursing & 3 & 4 \\
\hline & Psychiatric nursing & 2 & 3 \\
\hline & Nursing administration & 1 & 1 \\
\hline & Bioethics & 1 & 1 \\
\hline & Not nursing & 1 & 1 \\
\hline & No response & 14 & 20 \\
\hline \multirow{3}{*}{ Types of universities } & University & 45 & 64 \\
\hline & College & 18 & 26 \\
\hline & No response & 7 & 10 \\
\hline \multirow{4}{*}{ Managing organizations } & Educational corporations & 40 & 57 \\
\hline & National government & 13 & 19 \\
\hline & Local governments & 12 & 17 \\
\hline & No response & 5 & 7 \\
\hline
\end{tabular}


Nursing ethics was an independent course at $76 \%$ of all universities. It was not an independent course at $7 \%$ of the universities and was incorporated in the area of fundamental nursing at $16 \%$ of the universities. Why the subjects took charge of nursing ethics were: they had undertaken research work in nursing ethics (27\%), they had taught nursing ethics (26\%), their academic specialty was nursing ethics $(10 \%)$, they belonged to the discipline of fundamental nursing $(14 \%)$, they were nursing specialists $(6 \%)$, they were ethics specialists (4\%), other reasons (7\%), and no response $(6 \%)$. Seven percent of the respondents stated that they had taken nursing ethics courses themselves and $89 \%$ responded that they hadn't. Of those who had taken the course, five educators had taken an independent nursing ethics course; of those who had not taken the course, 26 educators had learned nursing ethics in class in the areas of fundamental nursing.

\subsection{Contents and methods of education of an indepen- dent subject of nursing ethics in Japan}

Forty-four respondents reported that there were some independent courses of nursing ethics. An overview of those courses is provided in Table 2. Most of these were required courses; while many were assigned to the third year of school, when there are no practical training, some of the courses were distributed throughout the four years of university education. In all cases, the educational methods comprised classroom lectures and group work. In most cases, the method of evaluation was reports $(57 \%)$, and in most cases, there was one person in charge of the course (66\%). The educational goals of nursing ethics were as follows: learning basic knowledge related to nursing ethics (29\%), improving ethical sensibilities $(23 \%)$, learning processes to solve ethical problems (11\%), cultivating the ability to make ethical judgments (7\%), learning ethical decision-making (6\%), understanding ethical dilemmas (3\%), and learning basic knowledge related to bioethics (1\%).

The educational content of nursing ethics taught as independent courses and nursing ethics taught as part of basic nursing programs are provided in Table 3. In more than $90 \%$ of all nursing ethics courses, students learned the Code of Ethics for Nurses (the Japanese Nursing Association), and in more than $80 \%$ cases, ethical principles, definitions of nursing ethics, the ICN Code of Ethics for Nurses, advocacy, patients' bill of rights, informed consent, self-determination, confidentiality, and ethical dilemmas were included in the curriculum. More than $70 \%$ pertained to differences between law and ethics, the Declaration of Lisbon, the Declaration of Helsinki, caring, human rights, protection of personal information, ethical problems, and ethical decision-making. Major educational topics were patients' rights, ethics codes and ethical guidelines, confidentiality and protection of personal information, and analytic approaches to ethical problems.

\subsection{Difficulties that nursing ethics educators faced and the reasons}

In response to the question regarding difficulties with teaching the course, $37 \%$ responded that they "felt it was difficult", $50 \%$ responded that they "felt it was difficult to some extent", $6 \%$ responded that they "felt it was not very difficult", and $3 \%$ responded they "felt it was not difficult". A total of $87 \%$ of the subjects responded that they either "felt it was difficult" or "felt it was difficult to some extent", which indicated that many educators experienced some difficulties. We asked the respondents to write freely about the reasons for the difficulties, and showed them in Table 4. The following nine categories of the reasons for the difficulties were extracted from the respondents' descriptions: school years to which the course was assigned were not appropriate; unable to form a specific image of clinical practice; what topics should be selected and how students should be educated with them; poor ability of educators and lack of educators; students don't obtain a deep understanding; educators raise an issue with no solution; insufficient amount of class time; quality and awareness of students; difficulty in prompting students to think deeply about issues raised in class. Twenty-one sub categories to give more specific descriptions of those difficulties were extracted.

The specific descriptions of "school years to which the course was assigned were not appropriate" were: "too early if students in their lower grades take the course"; "too late if students in their higher grades take the course"; "students shouldn't take the course at the same timing as their major subjects". The specific descriptions of "unable to form a specific image of clinical practice" were: "due to students' lack of practical experience" and "due to students' lack of clinical experience". The specific descriptions of "what topics should be selected and how students should be educated with them" were: "what topics in what domains should be selected"; "what terms and concepts should be explained". The specific descriptions of "poor ability of educators and lack of educators" were: "it's not appropriate for only one educator to take charge of the course"; "lack of educators' expertise". The specific descriptions of "students don't obtain a deep understanding" were: "students" learning is limited to a conceptual understanding"; "students' learning is limited to a superficial understanding". The specific descriptions of "educators raise an issue with no solution" were: "educators prompt students to think about issues with no correct solution"; "there is no solution to the ethical issues raised in the course"; "students seek a correct solution". The specific descriptions of "in- 
sufficient amount of class time" were: "total class hours are insufficient"; "time for practical activities is insufficient". The specific descriptions of "quality and awareness of students" were: "students' lack of sensitivity"; "students' lack of awareness regarding human rights"; "students are inexperi-

Table 2. Overview of nursing ethics courses $(n=44)$

\begin{tabular}{|c|c|c|c|}
\hline \multicolumn{2}{|c|}{ Nursing ethics course $(n=44)$} & \multirow{2}{*}{$\begin{array}{l}\text { Number of respondents } \\
42\end{array}$} & \multirow{2}{*}{$\begin{array}{l}\text { Percentage (\%) } \\
95\end{array}$} \\
\hline Pequired/ontional & Required subject & & \\
\hline Requirea/optional & optional subject & 2 & 5 \\
\hline \multirow{2}{*}{ Units } & 1 unit & 37 & 84 \\
\hline & 2 units & 7 & 16 \\
\hline \multirow{4}{*}{ Assigned school year } & 1st year & 7 & 16 \\
\hline & 2nd year & 11 & 25 \\
\hline & 3rd year & 16 & 36 \\
\hline & 4th year & 10 & 23 \\
\hline \multirow{2}{*}{ Type of class } & Lectures & 0 & 0 \\
\hline & Lectures and group work & 44 & 100 \\
\hline \multirow{3}{*}{ Textbook } & Available & 22 & 50 \\
\hline & No available & 21 & 48 \\
\hline & No response & 1 & 1 \\
\hline \multirow{2}{*}{ Methods of evaluation } & Reports & 38 & 57 \\
\hline & Test & 23 & 34 \\
\hline \multirow{5}{*}{$\begin{array}{l}\text { Number of educators in } \\
\text { charge of the class }\end{array}$} & 1 people & 29 & 66 \\
\hline & 2 people & 8 & 18 \\
\hline & 3 people & 4 & 9 \\
\hline & 4 people & 1 & 2 \\
\hline & Over 5 people & 2 & 5 \\
\hline \multirow{9}{*}{ Educational goals } & Learning basic knowledge related to nursing ethics & 20 & 29 \\
\hline & Improving ethical sensibilities & 16 & 23 \\
\hline & Learning processes to solve ethical problems & 8 & 11 \\
\hline & Cultivating the ability to make ethical judgments & 5 & 7 \\
\hline & Learning ethical decision-making & 4 & 6 \\
\hline & Understanding ethical dilemmas & 2 & 3 \\
\hline & Learning basic knowledge related to bioethics & 1 & 1 \\
\hline & Other & 8 & 11 \\
\hline & No response & 6 & 9 \\
\hline
\end{tabular}

3.4 Educational challenges raised by nursing ethics educators

Educational challenges raised by nursing ethics educator in a multiple-response way were: school years to which the course was assigned (56\%), teaching methods $(56 \%)$, contents of education (43\%), class hours and credits $(33 \%)$, methods of evaluation (33\%), expertise of educators (29\%), and textbooks and reading materials $(9 \%)$. More than half enced and immature". The specific descriptions of "difficulty in prompting students to think deeply about issues raised in class" were: "students prefer memorizing to thinking"; "students are not ready to think about nursing ethics".

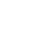

of the respondents selected school years to which the course was assigned and teaching methods. The specific descriptions that had been written by the respondents were indicated in Table 5 according to 6 core categories: school years to which the course was assigned, teaching methods, contents of education, class hours and credits, methods of evaluation, expertise of educators. 
Table 3. Educational contents of nursing ethics courses ( $n=70$, multiple answers)

\begin{tabular}{|c|c|c|c|}
\hline \multicolumn{2}{|l|}{ Educational contents } & \multirow{2}{*}{$\begin{array}{l}\text { Number of respondents } \\
42\end{array}$} & \multirow{2}{*}{$\begin{array}{l}\text { Percentage (\%) } \\
60\end{array}$} \\
\hline \multirow{2}{*}{ Ethical theory and ethical principles } & Ethical theory & & \\
\hline & Ethical principles & 62 & 89 \\
\hline \multirow{5}{*}{ Definitions } & Nursing ethics & 59 & 84 \\
\hline & Bioethics & 31 & 44 \\
\hline & Ethics & 45 & 64 \\
\hline & Morality & 33 & 47 \\
\hline & The difference of law and ethics & 50 & 71 \\
\hline \multirow{5}{*}{ Ethical codes and policies } & Code of Ethics for Nurses & 66 & 94 \\
\hline & ICN Code of Ethics for Nurses & 57 & 81 \\
\hline & International Code of Ethics for Midwives & 9 & 13 \\
\hline & Declaration of Lisbon & 51 & 73 \\
\hline & Declaration of Helsinki & 50 & 71 \\
\hline \multirow{2}{*}{ History } & The history of nursing ethics & 44 & 63 \\
\hline & The history of bioethics & 26 & 37 \\
\hline \multirow{4}{*}{ Basic concepts in nursing ethics } & Advocacy & 61 & 87 \\
\hline & Caring & 55 & 79 \\
\hline & Accountability & 34 & 49 \\
\hline & Corporation & 25 & 36 \\
\hline \multirow{2}{*}{$\begin{array}{l}\text { The sanctity of life and quality of } \\
\text { life }\end{array}$} & The sanctity of life & 47 & 67 \\
\hline & Quality of life & 28 & 40 \\
\hline \multirow{4}{*}{ Issues related to patient rights } & Human rights & 51 & 73 \\
\hline & Patients’ rights & 60 & 86 \\
\hline & Informed consent & 58 & 83 \\
\hline & Self determination & 61 & 87 \\
\hline \multirow{2}{*}{$\begin{array}{l}\text { Confidentiality obligation and the } \\
\text { protection of personal information }\end{array}$} & Confidentiality obligation & 59 & 84 \\
\hline & Protection of personal information & 51 & 73 \\
\hline \multirow{4}{*}{$\begin{array}{l}\text { Analytical approaches to ethical } \\
\text { problems }\end{array}$} & Ethical dilemma & 61 & 87 \\
\hline & Ethical problem & 52 & 74 \\
\hline & Ethical decision making & 52 & 74 \\
\hline & Analytical approaches of clinical ethics & 48 & 69 \\
\hline \multicolumn{2}{|l|}{ Safety and risk management } & 17 & 24 \\
\hline \multirow{2}{*}{ Research ethics } & Protection of human rights in research & 24 & 34 \\
\hline & Guidelines of research ethics & 14 & 20 \\
\hline \multicolumn{2}{|c|}{ Ethics in each area of the nursing profession } & 13 & 19 \\
\hline \multicolumn{2}{|c|}{ Ethical problems encountered by nursing students in the course of nursing practice } & 45 & 64 \\
\hline
\end{tabular}

There were 13 categories under 6 core categories. The first core category, school years to which the course was assigned, had two categories: the course should be assigned in tandem with practical training; the course should be divided into two parts and each should be assigned separately. The second core category, class hours and credits, had one category, class hours should balance with credits. The third core category, contents of education, had five categories: systematic and continuous accumulation; selection of cases; current clinical circumstances should be incorporated into education; learning bioethics as a whole; cultivating the ability to think. The fourth core category, teaching methods, had two categories: conducting group work; improving case discussions. The fifth core category, methods of evaluation, had two categories: ambiguous evaluation criteria; the scope of evaluation. The sixth core category, expertise of educators, had one category, the ability of educators to link classroom learning and practical training. 
Table 4. Reasons for difficulties in teaching nursing ethics $(n=61)$

\begin{tabular}{|c|c|}
\hline Category & Subcategory \\
\hline \multirow{3}{*}{$\begin{array}{l}\text { School years to which the course was assigned were } \\
\text { not appropriate }\end{array}$} & Too early if students in their lower grades take the course \\
\hline & Too late if students in their higher grades take the course \\
\hline & $\begin{array}{l}\text { Students shouldn't take the course at the same timing as their major } \\
\text { subjects }\end{array}$ \\
\hline \multirow{2}{*}{ Unable to form a specific image of clinical practice } & Due to students' lack of practical experience \\
\hline & Due to students' lack of clinical experience \\
\hline \multirow{2}{*}{$\begin{array}{l}\text { What topics should be selected and how students } \\
\text { should be educated with them }\end{array}$} & What topics in what domains should be selected \\
\hline & What terms and concepts should be explained \\
\hline \multirow{2}{*}{ Poor ability of educators and lack of educators } & It's not appropriate for only one educator to take charge of the course \\
\hline & Lack of educators' expertise \\
\hline \multirow{2}{*}{ Students don’t obtain a deep understanding } & Students’ learning is limited to a conceptual understanding \\
\hline & Students' learning is limited to a superficial understanding \\
\hline \multirow{3}{*}{ Educators raise an issue with no solution } & Educators prompt students to think about issues with no correct solution \\
\hline & There is no solution to the ethical issues raised in the course \\
\hline & Students seek a correct solution \\
\hline \multirow{2}{*}{ Insufficient amount of class time } & Total class hours are insufficient \\
\hline & Time for practical activities is insufficient \\
\hline \multirow{3}{*}{ Quality and awareness of students } & Students’ lack of sensitivity \\
\hline & Students’ lack of awareness regarding human rights \\
\hline & Students are inexperienced and immature \\
\hline \multirow{2}{*}{$\begin{array}{l}\text { Difficulty in prompting students to think deeply about } \\
\text { issues raised in class }\end{array}$} & Students prefer memorizing to thinking \\
\hline & Students are not ready to think about nursing ethics \\
\hline
\end{tabular}

In Table 5, there were 25 subcategories to suggest specific educational challenges. The first core category, school years to which the course was assigned, had five subcategories. The respondents wished students to take the course in both lower and higher grades, since their proficiency in each period allowed them to be ready to learn. The second core category, class hours and credits, had three subcategories. The respondents thought that more than two credits were more suitable than one credit.

The third core category, contents of education, had nine subcategories. The subcategory, "presenting familiar and specific examples" represented the two remarks below.

-I need to suggest a case and a method by which students can put themselves in other people's place I need to think about the cases and methods that I can conceive myself.

-I want to give typical ethical problems in each domain that students readily encounter.

The subcategory, "gap between the ideal and the reality", represented the following remark.

-How should I explain the gap between princi- ples and actual clinical settings?

The subcategory, "conducting the basic course and practical course separately", represented the following remark.

-The course should be divided into two parts: basic knowledge and concrete examination of ethical judgment.

The subcategory, "strengthening the link to nursing practice", represented the following remark.

-All nursing practical training establish each goal related to nursing ethics, but it isn't built up in a systematic way or evaluated.

The fourth core category, teaching methods, had four subcategories. The subcategory, "investigating the ideal number of students in one group for group work", represented the following remark.

-Because of the large number of students, it is difficult to arrange a group work environment.

The subcategory, "ensuring discussion time", represented the following remark. 
-We give many opportunities to discuss and ana-

lyze cases thoroughly.

The fifth core category, methods of evaluation, had three subcategories. The subcategory, "the difficulty of assigning evaluation points", represented the following remark.

-I wonder how to evaluate students' reports.
The sixth core category, expertise of educators, had one subcategory. The subcategory, "giving significance to nursing practice and classroom learning", represented the following remark.

-When students encounter ethical problems in practical training, do educators in charge give the meaning of them to the students?

Table 5. Educational challenges related to nursing ethics subjects

\begin{tabular}{|c|c|c|}
\hline Core category & Category & Subcategory \\
\hline \multirow{5}{*}{$\begin{array}{l}\text { School years to which } \\
\text { the course was assigned }\end{array}$} & \multirow{2}{*}{$\begin{array}{l}\text { The course should be assigned in } \\
\text { tandem with practical training }\end{array}$} & Assigning (the course) prior to basic nursing practice \\
\hline & & Assigning (the course) after nursing practice \\
\hline & \multirow{3}{*}{$\begin{array}{l}\text { The course should be divided into two } \\
\text { parts and each should be assigned } \\
\text { separately }\end{array}$} & Assigning (the course) in the first and last grades \\
\hline & & $\begin{array}{l}\text { Assigning (the course) in the first half of university and } \\
\text { immediately after nursing practice }\end{array}$ \\
\hline & & Assigning (the course) over different school years \\
\hline \multirow{3}{*}{ Class hours and credits } & \multirow{3}{*}{$\begin{array}{l}\text { Class hours should balance with } \\
\text { credits }\end{array}$} & Two credits are insufficient \\
\hline & & Two credits are preferable \\
\hline & & One credit is insufficient \\
\hline \multirow{9}{*}{ Contents of education } & \multirow{3}{*}{$\begin{array}{l}\text { Systematic and continuous } \\
\text { accumulation }\end{array}$} & Conducting the basic course and practical course separately \\
\hline & & Strengthening the link to nursing practice \\
\hline & & $\begin{array}{l}\text { Strengthening the link between the basic courses and } \\
\text { specialized courses }\end{array}$ \\
\hline & \multirow[b]{2}{*}{ Selection of cases } & Presenting familiar and specific examples \\
\hline & & $\begin{array}{l}\text { Listening to the stories of individuals involved (in ethics } \\
\text { problems) }\end{array}$ \\
\hline & \multirow{2}{*}{$\begin{array}{l}\text { Current clinical circumstances should } \\
\text { be incorporated into education }\end{array}$} & Not dissociating from clinical settings \\
\hline & & Gap between the ideal and the reality \\
\hline & Learning bioethics as a whole & Learning not only nursing ethics but also bioethics as a whole \\
\hline & Cultivating the ability to think & Cultivating ethical reasoning skills \\
\hline \multirow{4}{*}{ Teaching methods } & \multirow[b]{2}{*}{ Conducting group work } & Promoting discussion \\
\hline & & $\begin{array}{l}\text { Investigating the ideal number of students in one group for } \\
\text { group work }\end{array}$ \\
\hline & \multirow{2}{*}{ Improving case discussions } & Exercises that provide students the opportunity to think \\
\hline & & Ensuring discussion time \\
\hline \multirow{3}{*}{ Methods of evaluation } & \multirow{2}{*}{ Ambiguous evaluation criteria } & The difficulty of assigning evaluation points \\
\hline & & Not accustomed to evaluation \\
\hline & The scope of evaluation & Performing evaluation of nursing practice \\
\hline Expertise of educators & $\begin{array}{l}\text { The ability of educators to link } \\
\text { classroom learning and practical } \\
\text { training }\end{array}$ & Giving significance to nursing practice and classroom learning \\
\hline
\end{tabular}

\subsection{Association between ethics education and nursing practice}

In response to the question regarding whether the respondents were conscious of an association between nursing ethics class and nursing practice, it was revealed that $63 \%$ were "aware" about such an association, 28\% were "aware to some degree", $6 \%$ were "not very aware", and $0 \%$ were "not aware at all." When those who responded as being "aware" and those who responded as being "aware to some degree" were combined, a total of more than $90 \%$ respondents were aware 
about such an association between their classes and nursing practice. The following ten categories consisting of specific awareness were extracted from the data: "the use of cases", "discussions of ethical problems", "handling of ethical problems encountered by students in nursing practice", "approach to ethical problems", "confidentiality and protection of personal information", "patients' rights and self-determination", "learning of the ethics codes and principles", "the concept and manifestation of caring", "the manner in which medical professionals interact with patients," and "issues to be noted during nursing practice as a nursing student". Twenty-two sub categories were clarified as concrete conscious measures.

In "the use of cases", the subjects dealt with: "issues that students may encounter during nursing practice"; "issues that students may encounter in future clinical practice"; "characteristic ethical problems in each nursing specialty". The subjects practiced an approach to "conduct group work" and "express thoughts and ideas to one another", concerning "discussions of ethical problems". In "handling of ethical problems encountered by students in nursing practice", the subjects had students: "write a paper" of practical training; "reflect on and discuss experiences"; "include experiences during nursing practice in classes". In order to make an "approach to ethical problems", the subjects encouraged the students to: "promote awareness"; "investigate the manner of handling problems"; "present criteria for judgment and perspectives". With regard to "confidentiality and protection of personal information", the subjects took up specific clinical cases in class in which how to "protect privacy" and "protect personal information" were clarified. In "patients' rights and self-determination", the faculty took up specific cases of: "patients' rights"; "patients' self-determination"; "informed consent" in class. In "learning of the ethics codes and principles", the teachers conducted a class in which students could concretely "learn the Code of Ethics for Nurses" and "four principles of medical ethics and its application". With regard to "the concept and manifestation of caring", the faculty developed classes for the purpose of students "learning the concept of caring" and "learning concretely caring in clinical settings". In order to learn "the manner in which medical professionals interact with patients", the subjects made students aware of "the importance of dealing with individuals in a neutral manner". In "issues to be noted during nursing practice as a nursing student", the subjects prompted students to "clarify the scope of responsibilities as a nursing student" in class.

\section{Discussion}

This survey has contributed to revealing the data, that few background surveys of nursing ethics educators have been

Published by Sciedu Press conducted in Japan. ${ }^{[39]}$ Many of those involved in nursing ethics education were nursing professionals (professors) with work history as a researcher of nursing ethics or as an educator.

The results of this survey showed that nursing ethics education was delivered as a compulsory subject in most universities, and the major purposes were to acquire basic knowledge and improve ethical sensibilities. In order to improve ethical sensibilities, the importance of awareness about ethical problems and thinking processes to approach ethical problems have been emphasized. Previous studies have indicated the importance of group discussion, ${ }^{[10,14,15]}$ and this survey demonstrated consistent results. Concerning the assignment of the nursing ethics course, school years in which nursing ethics education should be provided has not been standardized.

This survey's results revealed that most of the respondents were aware of the association between nursing ethics class and practical training. Those educators carried out pretraining education with ethical problems that nursing students might encounter during their practical training. Likewise, post-training education was performed using students' reflection papers on the ethical problems they experienced during training. While previous research ${ }^{[36]}$ reported on the necessity of emphasizing the association between nursing ethics class and practical training, the respondents of this survey were well aware of it and tried specific approaches. According to a survey, conducted by the author, of nursing faculty members who were in charge of practical training at some universities in Japan, nursing students consulted their teachers on ethical problems they encountered in practical training. It was assumed that students should be provided with an opportunity to associate classroom learning with what occurred in practical training. ${ }^{[40]}$ To improve this situation, it seemed to be effective for nursing ethics educators to cooperate with teachers in charge of practical training to examine what and how students should learn in classes. However educators have not fully discussed improving ethical skills of nursing students through nursing education. ${ }^{[28]}$

This survey demonstrated that patients' rights, confidentiality and protection of personal information, analytical approaches to ethical problems, and ethical theories and principles were common topics in nursing ethics education. Some previous research indicated that these topics were included in education carried out in many foreign countries. ${ }^{[14,20]}$ What nurses and nursing ethics educators thought necessary did not differ between Japan and other countries. ${ }^{[26]}$ This survey indicated that education to cultivate the ability to analyze ethical problems, ${ }^{[35]}$ which had long been pursued, was incorporated into 
Japanese nursing ethics classes.

This survey demonstrated that nearly $90 \%$ of respondents found it difficult to teach nursing ethics. This was caused by what educators were not able to change readily: 1) curriculum (school years to which the course was assigned, class hours and credits), 2) students' circumstances (inability to imagine clinical settings), 3) students' abilities (immature and lack of sensitivity), 4) the characteristics of ethical problems (issues with no solution, difficulty in finding a solution to an issue), and 5) educators' abilities.

1) Curriculum: School years to which the course was assigned should be examined based on educators' ideas about the association with practical training and separate assignment of the course divided into two parts to accomplish systematic learning over the entire school period of four years. A case report on systematic and continuous education suggested an example in which students learned nursing ethics in the first and fourth years, during which there was no practical training. ${ }^{41]}$ Since the issues of curriculum led to the difficulty that educators had in teaching nursing ethics, each university management should have a discussion with educators about the assignment of the course and its grounds to resolve the difference of opinions. Even though there are a variety of opinions regarding the assignment of nursing ethics classes, ${ }^{[9,27]}$ it is necessary to re-examine the goals to be accomplished, based on nursing students' readiness to learn in each school year.

2) Students' circumstances: One of the difficulties educators had was caused by a reasonable, unavoidable reality that students were unable to form a specific image of clinical practice. Educators needed to create classes that included the perspectives of both students and clinicians in the context of nursing practice.

3) Students' abilities: Educators thought that students' lack of sensitivity and awareness regarding human rights were issues in teaching nursing ethics. As shown in the results, the purpose of classes of nursing ethics included "raising ethical sensitivity," and it seemed necessary to have a view that these classes themselves were a process of fostering sensitivity. Likewise, students should become aware of their lack of the sense of human rights in nursing ethics classes, which more than $70 \%$ of the subjects were taught in their class. In further research, it is necessary to clarify the grounds on which educators judge that the students are lacking in sensitivity and awareness regarding human rights.

4) The characteristics of ethical problems: While students asked for answers, educators themselves also had a strong awareness of the fact that there was no answer. Even if there is no single correct answer, it is possible to obtain a conclusion of the best judgment in each case. It is of important to reasonable argue about the best means and to gain a perspective necessary for ethical problems. It has been said that developing the ability of moral reasoning in nursing ethics education is important. ${ }^{[17,42,43]}$

5) Educators' abilities: It was revealed in this survey that nursing ethics educators were concerned about their teaching abilities. It appeared that they taught nursing ethics because they belonged to the field of fundamental nursing and were not specialists in the field of ethics. Lack of skills and abilities to link classroom education to nursing practice was identified as a reason for the difficulties in providing education. This suggested that it was necessary to discuss what expertise nursing ethics educators should hold. This survey asked what types of nursing ethics education that the educators had obtained. Few respondents took an independent course of nursing ethics when the educators received the basic education. Many of them studied nursing ethics as part of fundamental nursing education. Previous research ${ }^{[16]}$ also pointed out the necessity of educational programs for educators who taught nursing ethics.

This survey demonstrated the status and challenges of nursing ethics education in Japanese nursing education from educators' perspectives, even though the low return rate of the questionnaires made it difficult to gain generalized results. Further examination about what and how students think they should learn is for the coming.

\section{Conclusion}

This survey revealed that nursing ethics is a required course in Japanese nursing bachelor's degree programs, which nursing professionals with a high status like professors taught. Nursing ethics education in Japan placed importance on methods of group discussion based on case studies. Patients' rights, confidentiality, and analytical approaches to ethical problems were main educational topics. Educators were very aware of the association between nursing ethics practical training in their teaching activities. Many of the subjects faced difficulties in nursing ethics education: curriculum, students' circumstances, students' abilities, the characteristics of ethical problems, and educators' abilities. This survey indicated that discussions regarding what educational goals in what school year should be offered to students were needed at each university. Cooperation between educators and practical training instructors on the contents of education, and a clear definition of expertise necessary for teaching nursing ethics were challenges to be accomplished as well. 


\section{FUNDING}

The present study was supported by the Ministry of Education, Culture, Sports, Science and Technology (MEXT) Grants-in-Aid for Scientific Research (KAKENHI) (Young Researcher [B] Creation of Structured Bioethical Education in Undergraduate Nursing Education [principal researcher: Mari Tsuruwaka] No. 24790514).

\section{ACKNOWLEDGements}

The author would like to thank all the participants for their time.

\section{CONFLICTS OF INTEREST Disclosure}

The author declares that there is no conflict of interest statement.

\section{REFERENCES}

[1] Stites SD, Clapp J, Gallagher S, et al. Moving Beyond the Theoretical: Medical Students' Desire for Practical, Role-Specific Ethics Training. AJOB Empir Bioeth. 2018; May 4: 1-28. PMid:29727598 https://doi.org/10.1080/23294515.2018.1472149

[2] Kaldjian LC, Rosenbaum ME, Shinkunas LA, et al. Through students' eyes: ethical and professional issues identified by third-year medical students during clerkships. J Med Ethics. 2012; 38(2): 130132. PMid:21947811 https://doi.org/10.1136/medethics-2 011-100033

[3] Hindmarch T, Allikmets S, Knights F. A narrative review of undergraduate peer-based healthcare ethics teaching. Int J Med Educ. 2015; 6: 184-190. PMid:26668050 https://doi.org/10.5116/ ijme.5650.54ad

[4] Miñano R, Uruburu Á, Moreno-Romero A, et al. Strategies for Teaching Professional Ethics to IT Engineering Degree Students and Evaluating the Result. Sci Eng Ethics. 2017; 23(1): 263-286. PMid:26733408 https ://doi .org/10.1007/s11948-015-974 $6-\mathrm{x}$

[5] Culver SM, Puri IK, Wokutch RE, et al. Comparison of engagement with ethics between an engineering and a business program. Sci Eng Ethics. 2013; 19(2): 585-597. PMid:22212359 https: //doi.org/10.1007/s11948-011-9346-3

[6] Rushton CH, Kurtz M. Toward everyday ethics -strategies for shifting perspectives, AACN Adv Crit Care. 2017; 28(3): 291-298. PMid:28847865 https://doi.org/10.4037/aacnacc2017406

[7] Ulrich CM, Taylor C, Soeken K, et al. Everyday ethics: ethical issues and stress in nursing practice. J Adv Nurs. 2010; 65 (11): 2510-2519. PMid:20735502 https://doi .org/10.1111/j.1365-2648.20 $10.05425 . \mathrm{x}$

[8] Reed J, Ground I. Philosophy for nursing. London: Whurr Pub Ltd; 1997.

[9] Parsons S, Barker PJ, Armstrong AE. The teaching of health care ethics to students of nursing in the UK: a pilot study. Nurs Ethics. 2001; 8(1): 45-56. PMid:16010908 https ://doi .org/10.1177/ 096973300100800106

[10] Numminen O, van der Arend A, Leino-Kilpi H. Nurse educators' and nursing students' perspectives on teaching codes of ethics. Nurs Ethics. 2009; 16(1): 69-82. PMid:19103692 https://doi .org/10 .1177/0969733008097991

[11] Park EJ. The development and implications of a case-based computer program to train ethical decision making. Nurs Ethics. 2013; 20(8): 943-956. PMid:23702890 https ://doi .org/10.1177/09 69733013484489

[12] Krautscheid L. Embedding microethical dilemmas in high-fidelity simulation scenarios: preparing nursing students for ethical practice. J Nurs Edu. 2017; 56(1): 55-58. PMid:28118477 https: //doi.org/10.3928/01484834-20161219-11

Published by Sciedu Press
[13] Russell M. Teaching civility to undergraduate nursing students using a virtue ethics-based curriculum. J Nur Edu. 2014; 53(6): 313-319. PMid:24814354 https ://doi .org/10.3928/01484834-20140 512-03

[14] Dinç L, Görgülü RS. Teaching ethics in nursing. Nurs Ethics. 2002; 9(3): 259-68. PMid:12035431 https://doi.org/10.1177/0969 73300200900305

[15] Kyle G. Using anonymized reflection to teach ethics: a pilot study Nurs Ethics. 2008; 15(1): 6-16. PMid:18096577 https://doi.or $\mathrm{g} / 10.1177 / 0969733007083931$

[16] Ramos FR, de Pires DE, Brehmer LC, et al. The discourse of ethics in nursing education: experience and reflections of Brazilian teachers case study. Nurse Educ Today. 2013; 33: 1124-1129. PMid:23317508 https://doi.org/10.1016/j.nedt.2012.12.011

[17] Torabizadeh C, Homayuni L, Moattari M. Impacts of Socratic questioning on moral reasoning of nursing students. 2018; 25(2): 174-185.

[18] Chao SY, Chang YG, Yang SC, et al. Development, implementation, and effects of an integrated web-based teaching model in a nursing ethics course. Nurse Edu Today. 2017; 55: 31-37. PMid:28511085 https://doi.org/10.1016/j.nedt.2017.04.011

[19] Hsu Li-Ling. Blended learning in ethics education: a survey of nursing students. Nurs Ethics. 2011; 18(3): 418-30. PMid:21558117 https://doi.org/10.1177/0969733011398097

[20] Kalaitzidis E, Schmitz K. A study of an ethics education topic for undergraduate nursing students. Nurse Educ Today. 2012; 32(1): 11115. PMid:21419533 https://doi.org/10.1016/j.nedt. 2011. 02.006

[21] Posluszny L, Hawley DA. Comparing professional values of sophomore and senior baccalaureate nursing students. J Nurs Edu. 2017; 56(9): 546-550. PMid:28876441 https://doi .org/10.3928/01 484834-20170817-06

[22] Park HA, Cameron ME, Han SS, et al. Korean nursing students' ethical problems and ethical decision making. Nurs Ethics. 2003; 10(6): 638-53. PMid:14650482 https://doi .org/10.1191/09697330 03ne653oa

[23] Hendricks-Ferguson VL, Ruebling I, Sargeant DM, et al. Undergraduate students' perspectives of healthcare prfessionals' use of shared decision-making skills. J Interpro Care. 2018; Mar 7: 1-9.

[24] Sinclair J, Papps E, Marshall B. Nursing students' experiences of ethical issues in clinical practice: A New Zealand Study. Nurs Educ Pract. 2016; 17: 1-7. PMid:27038081 https://doi.org/10.101 6/j.nepr.2016.01.005

[25] Ion R, DeSouza R, Kerin T. Teaching ethics: intersectionality, care failure and moral courage. Nurse Edu Today. 2018; 62: 98-100. PMid:29306753 https://doi.org/10.1016/j.nedt.2017.12 .023

[26] Harding T. Cultural safety: a vital element for nursing ethics. Nurs Prax N Z. 2013; 29(1): 4-11. PMid:23691756 
[27] Nolan PW, Markert D. Ethical reasoning observed: a longitudinal study of nursing students. Nurs Ethics. 2002; 9(3): 243-58. PMid:12035430 https://doi.org/10.1191/0969733002ne50 7oa

[28] Cannaerts N, Gastmans C, Bernadette Dierckx de Casterlé. Contribution of ethics education to the ethical competence of nursing students: Educators' and students' perceptions. Nurs Ethics. 2014; 21(8): 861-78. PMid:24714046 https ://doi.org/10.1177/09 69733014523166

[29] Ramos FR, Brehmer LC, Vargas MA, et al. Ethical conflicts and the prcess of refection in undergraduate nursing students in Brazil. Nurs Ethics. 2015; 22(4): 428-439. PMid:25096246 https : //doi .org/ 10.1177/0969733014538890

[30] Ministry of health, Labour and Welfare. The report of basic nursing education review conference. 2007. Available from: http: //www.mhlw.go.jp/shingi/2007/04/dl/s0420-13.pdf

[31] Yamada S, Hatano K, Onodera T. Nursing ethics education of nursing education. Nursing Education. 1999; 40(3): 204-8 Japanese.

[32] Katsuragawa J. Patient's advocacy and nurse: bioethical point of view. 2002; Waseda university master's thesis. Japanese.

[33] Tsuruwaka M, Kawakami Y. Examination of nursing ethics education in nursing bachelors programs from contents of syllabuses. Journal of Japanese Nursing Ethics. 2013; 5: 71-5. Japanese.

[34] Ito C, Ota K, Matsuda M. Educational content in nurse education in Japan: A Delphi study Nurs ethics. 2011; 18(3): 441-54 PMid:21558119 https: //doi .org/10.1177/09697330103855 30
[35] Katsuyama K, Katsuhara Y, Hoshi K, et al. Nursing ethics studies in Japan: a review over the last five years. Journal of Japanese Nursing Ethics. 2010; 2(1): 77-86. Japanese.

[36] Yamamoto M, Washio M, Iribe H. The present status of nursing ethics education in Japanese nursing colleges and schools: a survey. Journal of Japanese Nursing Ethics. 2015; 7(1): 77-85.

[37] Tsuruwaka M. Crucial ethical problem for Japanese nursing students at clinical settings. Journal of Nursing Education and Practice. 2015; 5(12): 17-24. https ://doi .org/10.5430/jnep.v5n12p17

[38] Nakao H. Nursing educators' recognition of ethical issues and its relationship to ethical education, Memoirs Dep. of Health Scis. Sch. of Med Kyushu Univ. 2007; 8: 69-76.

[39] Endo Y. Trends and tasks of studies on nursing ethics education focused on the side of educators, Research of medical health (Tsukuba international university). 2012; 3: 125-35. Japanese.

[40] Tsuruwaka M. Consulted ethical problems of clinical nursing practice: perspective of faculty members in Japan. BMC Nursing. 2017; 16(23): 1-9. https : //doi.org/10.1186/s12912-017-0217-3

[41] Imai N, Fukuroku K, Nakanishi Y, et al. The actual impact of gradual and continuing ethical education in School of Nursing, Faculty of Medicine Mie University Mie Nursing Journal. 2014; 16: 61-5. Japanese.

[42] McLeod-Sordjan R. Evaluating moral reasoning in nursing education. Nur Ehics. 2014; 21(4): 473-83. PMid:24225058 https: //doi.org/10.1177/0969733013505309

[43] Park M, Kjervik D, Crandell J, et al. The relationship of ethics education to moral sensitivity and moral reasoning skills of nursing students. Nurs Ethics. 2012; 19(4): 568-80. PMid:22691600 https://doi.org/10.1177/0969733011433922 